\title{
Legal Certainty of Tax Determination on acquisition Charges for Land and Building Rights (BPHTB) by Local Finance Board in Karanganyar
}

\author{
Abdullah Jamaludin \\ Lego Karjoko \\ Universitas Sebelas Maret \\ Indonesia
}

\begin{abstract}
Determination of tax on sales and purchase of land and / or building rights in Karanganyar District is often problematic. One of them is price gap transaction submitted by taxpayer with data held by Karanganyar Local Finance Board. The method used was empirical normative. The results of this study were in determining the actual transaction price based on the legal certainty theory, it needs to be clarified in terms of the regulations. Both the law and the local regulation were written in the sale and purchase of a land and / or building based on the transaction price. Transaction prices need to be explained in more detail. So it does not cause multiple interpretations, does not cause contradictions, and can be carried out, which is able to guarantee the rights and obligations of every citizen in accordance with the existing culture of society.
\end{abstract}

Keywords: Tax, Right on land/building, taxpayer

\section{A. Introduction}

\section{Background of Study}

State in holding governance and development uses budgets according to State Budget. One of the fund resource is tax sector. Based on Article 23 A of Constitution 45, tax and other levies that are coercive for the purposes of the state are regulated by law. Tax is collection from the public by the state (government) based on laws that are enforceable and indebted by those who are obliged to pay it with no direct performance (compensation / repayment), the results of which are used to finance state expenditure in government and development (Marihot Pahala Siahaan, 2013: 7). The tax itself is classified based on its collection agency, central tax and local tax. The central tax itself is taxes managed by central government mostly through Directorate General of Tax (DGT) and the units below it. While local taxes are taxes that are managed by regional government both at provincial and district / city which are administered by Regional Revenue Agency.

The central tax consists of income tax, value added tax, sales tax on luxury goods, stamp duty, land and building tax (PBB estate, forestry, mining). Local taxes consist of provincial and district / city taxes. According to Law Number 28 Year 2009 Concerning Regional Taxes and Regional Regulations, Article 2, provincial taxes consist of motor vehicle tax, motor vehicle transfer tax, motor vehicle fuel tax, surface water tax, and cigarette tax. While the District / city tax consists of hotel tax, restaurant tax, entertainment tax, advertisement tax, street lighting tax, nonmetallic mineral and rock tax, parking tax, ground water tax, swallow bird nest tax, rural and urban land and building tax, fees for obtaining land and / or building rights.

With these taxes, it is expected to be able to assist the government in implementing both central and regional government activities (provincial and district / city). In addition to helping in terms of governance, it can also assist the government in building infrastructure that can increase the prosperity and welfare of Indonesia people. This is in accordance with two tax functions, as follows (Siti Resmi, 2014: 3): Function of Budgetair (State Financial Resources)

Tax has a budgetary function meaning that tax is one source of government revenue to fund both routine and development expenditure. As a source of state finance, the government is trying to put as much money as possible into the national treasury. The effort was taken by extending and intensifying tax collection through improving various types of tax regulations such as Income Tax (PPh), Value Added Tax (VAT) and Sales Tax on Luxury Properties (PPnBM), Land and Building Tax (PBB), and others.

\section{a. Regularend Function}

Tax has a regulating function, which means that tax as a tool to regulate or implement government policies in the social and economic fields, as well as achieve certain objectives outside the financial sector. Humans need land to survive. 
Where land can be used to plant crops that support the sustainability of human life. Besides that, land can also be built as a building for human life. The current era of land began to be utilized for investment. Over time the land that was originally low in value will begin to rise in price. In investing mostly done by buying and selling. In buying and selling this land there are taxes that must be borne by both the seller and the buyer.

Land sale and purchase tax is a collection that must be paid by seller or buyer for the land which is the object of the sale and purchase. There are two kinds of taxes related to buying and selling land. The seller will be subject to income tax $(\mathrm{PPh})$, while the buyer will be subject to tax, it is Acquisition Charges for Land and Building Rights (BPHTB). The legal basis for the imposition of taxes for buyers is Law Number 2008 of 2009 concerning Regional Taxes and Retribution.

Indonesia consists of several provinces and cities / districts. One of them is Karanganyar District which has an area of 77,378.64 ha with 17 sub-districts, 15 urban-villages and 162 villages. Regarding the imposition of tax on sale and purchase of land rights, the tax on buyers is the autonomy of a region. Karanganyar District in managing tax is regulated and managed by Karanganyar Finance Board. For the transfer of land and building tax, it is regulated in Karanganyar District Regulation Number 14 of 2010 concerning Acquisition Charges for Land and Building Rights. The problem often faced by taxpayers in dealing with land and / or building transfer tax is amount of tax that must be paid by the taxpayer both by the seller and the buyer. The price is not in accordance with the reality of the transaction between the seller and the buyer. For example, the transaction that has been agreed between the seller and the buyer is Rp 100,000,000.00, but when the buyer will take care of the tax on the transfer of land and / or buildings to the Local Finance Board, the employee in charge of checking will adjust the buying and selling price with data owned by the Local Finance Board.

The data in a list price of land owned by the two agencies is a market price that has been done by the agency's research. However, the data owned are often different from the recognition of seller and buyer. So there is a difference in the sale and purchase price of a land. Based on the background above, this article chose the title "LEGAL CERTAINTY OF TAX DETERMINATION ONACQUISITION CHARGES FOR LAND AND BUILDING RIGHTS(BPHTB) BY LOCAL FINANCE BOARD IN KARANGANYAR"

\section{Problem Formulation}

Based on the background that has been described, this article will formulate the problem as follows:

a. What is regulation regarding Acquisition Charges for Land and Building Rights (BPHTB) in Karanganyar?

b. Does tax determination on Acquisition Charges for Land and Building Rights (BPHTB) by Karanganyar Finance Board can lead to legal certainty?

\section{B. Research Methods}

The research used was normative-empirical law research (combined). Normative Legal Research is a method of legal research conducted by examining library materials or secondary data. (Soerjono Soekanto \& Sri Mamudji, 2001: 1314) Empirical Law Research is a research method carried out to obtain primary data and find truth using thinking methods inductive and truth correspondence criteria and facts used to carry out the induction process of correspondence testing are up to date facts. Normative-Empirical Law (combined), legal research that examines the execution or implementation of positive legal provisions (legislation) factually in any particular legal event that occurs in society (Abdulkadir Muhammad, 2004: 134).

\section{Research Results and Discussion}

\section{Regulation regarding Acquisition Charges for Land and Building Rights (BPHTB) in Karanganyar}

According to Article 1 number 41 of Law Number 28 Year 2009 Concerning Regional Taxes and Retribution, the charges of acquiring land and building rights (hereinafter referred to as BPHTB) is a tax on the acquisition of land and / or building rights. While Article 1 Number 42, acquisition of rights to land and / or buildings is an act or legal event that results in the acquisition of rights to land and / or buildings by individuals or entities. BPHTB is included in the type of district / city tax. Having the understanding that the collection is carried out at the district / city level where the land and / or building which is located. The object of BPHTB isrights acquisition on land and / or buildings including the transfer of rights due to sale and purchase, exchange, grants, and others. In addition, it is also due to granting of new rights including the continuation relinquishment of rights or outside relinquishment of rights. Tax collection in BPHTB form conducted at the district / city level needs to be regulated using local regulations. For Karanganyar District itself regarding BPHTB regulated by Regional Regulation of Karanganyar District Number 14 Year 2010 Concerning Acquisition Charges for Land and Building Rights. In this local regulation regulates the amount of tariffs that need to be paid by taxpayers, the procedure for collection, and sanctions. This regulation refers to Law Number 28 Year 2009. 
2. Tax Determination on Acquisition Charges for Land and Building Rights (BPHTB) by Karanganyar Local Finance Board.

Law Number 32 of 2004 concerning Regional Government states that one source of regional income is from Regional Taxes. Especially for Local Taxes there are types of taxes that have been levied by the government to be transferred to local taxes. BPHTB is one type of tax whose authority is levied by the government. This is intended to increase the accountability of local governments in the implementation of regional autonomy.

The implementation of BPHTB in the regions is directed at efforts to equalize and based on the principle of justice. BPHTB collection is carried out by optimizing the function of the regional apparatus, guided by the authority of the district and needing to involve cooperation with notaries / officials land deeds and other relevant agencies. Fees for the acquisition of land and building rights, hereinafter referred to as BPHTB, are taxes on rights acquisition on land and / or building. Such acquisition is an act or legal event that results in the right acquisition on land and / or building by an individual or legal entity. This tax is levied by the District or city government. The individual or entity that deposits this tax is from the buyer.

The object of BPHTB is the rights acquisition on land and / or building based on Article 2 paragraph (2) of Law Number 20 Year 2000 includes:

1. Transfer of rights due to:

a. Sell and purchase;

b. trade-off;

c. grant;

d. testamentary grants;

e. inheritance;

f. revenue in a company or other legal entity;

g. Split of rights which results in transfer;

h. Appointment of buyers at auction;

i. Implementation of the judge's decision that has permanent legal force;

j. Business combination;

k. Business consolidation Business expansion;

1. Gift.

2. Granting of new rights, because

a. Continuation relinquishment of rights;

b. outside relinquishment of rights

The basis for imposition in BPHTB Law Number 28 Year 2009 Concerning Regional Taxes and Retribution Article 87 paragraph 2 letter a sale and purchase is market value. Whereas regarding the amount of the acquisition of non-taxable tax object is set at Rp 60,000,000.00 (sixty million rupiah) for each taxpayer. Tariffs from BPHTB are set at 5\% (five percent) in accordance with District Regulation Karanganyar Number 14 of 2010. In checking the tax on the acquisition of land and building rights, according to PP Number 55 Year 2016 Article 29 paragraph 1 the relevant service will examine the SSPD BPHTB which includes the following:

a. tax object number in BPHTB SSPD approriate with tax object number in SPPT photocopy or other proof of payment of PBB-P2 and in PBB-P database;

b. NJOP land per square meter in BPHTB SSPD approriate with NJOP per square meter in PBB- P-2 database;

c. NJOP buildings per square meter in BPHTB SSPD approriate with NJOP buildings per square meter in PBB-P2 database;

d. Validity of BPHTB calculation which includes the acquisition value of tax objects, tariffs, imposition of certain tax objects, BPHTB owed or payable; and

e. Validity of BPHTB calculation deposited, including the amount of the reduction calculated by itself. SSPD BPHTB research process is carried out no later than 1 (one) working day since it is received in full SSPD BPHTB for on-site research. If based on SSPD BPHTB research, the amount of tax is smaller than the amount of tax owed, the taxpayer must pay the difference.

Often in dealing with the sale and purchase tax of land ownership rights, the tax payers are at a price determined by Local Finance Board and Tax Service Office. For example, the taxpayer submits an application for tax validation of Rp $100,000,000.00$ (one hundred million rupiah), this price is the price agreed upon by the seller and buyer. However, during tax research process the prices determined by the two agencies are different. 
The tax research for Karanganyar was first submitted by BPHTB to Karanganyar Local Finance Office. After the file is complete, the request is then examined by BKD verification team. In researching the team checked location, land area, and land market price.

From interviews conducted with BKD verification team, the market price was obtained from data that team obtained from the apprisial (in this case cooperating with a third party to estimate the market price). If the price submitted by taxpayer is very different from data held by $\mathrm{BKD}$, the team will immediately check the location to obtain actual data. After conducting a field check, team verification then called the taxpayer concerned to come to BKD and be asked for information on the sale and purchase made.

This is where the tax "bargaining" between team verification and taxpayer usually occurs. The team interviewed taxpayers about transaction validity that had been done. If the team feels unfair, the team will raise the price of the tax in accordance with agreement between team and taxpayer. Based on the example above, if the price that must be paid by taxpayers is deficient, taxpayers must first in order to obtain tax validation for land rights purchase. If not paid immediately and after the deadline will be subject to fines.

According to P.J.A. Adriani "Taxes are collection to the state (which can be imposed), which are owed by those who are obliged to pay them according to regulations with no achievements, who can be directly appointed, and whose use is to fund public expenditures related to the State's task of administering government ".

The elements of tax definition described above includes:

a. Tax is a contribution to the state (which is required)

Meaning: everyone who gets a certain income must submit a portion of his wealth income to the state and the law is compulsory, both in the form of legal entities and individuals.

b. Taxes can be imposed

Meaning: only the state has the right to collect taxes. These contributions are in the form of money (not goods). If certain taxpayers do not pay their taxes, both to regional and central governments, the tax authorities will impose harsh sanctions on him, that is, taxpayer goods will be confiscated both movable and immovable property by bailiff and the goods will be auctioned and results of auction will be state own to develop the country.

c. Under the law

Meaning: tax is levied based on the strength of the law and its implementing regulations. These tax arrangements must not be based on regulations that are under the law.

d. No Rewards (contra-achievement)

Meaning: everyone who pays taxes does not get a direct contra from the government. Tax payments cannot be pointed out. There is individual contra by the government.

e. For the benefit of the community

Meaning: state tax revenue is used for matters relating to general public welfare. Used to fund state households, ie expenditures that benefit the wider community. One element of taxation is that taxes can be imposed, which implies that the state is obliged to force someone to pay taxes on certain acts it is the sale and purchase of land rights. In accordance with the 1945 Constitution Article 23 letter A which reads: "Taxes and other retributions that are coercive for the purposes of the state are regulated by law."

So in determining the tax carried out by BKD and Tax Office as if there was a compulsion to pay the sale and purchase tax on land rights. This is done so that taxpayers pay taxes according to the actual transaction prices they do, there is no counterpart in the transaction price just to reduce the amount of tax payments paid.

However, of course there is a reason why the taxpayer submits the tax which he paid is far from the data owned by the two agencies. One of them was at that time the seller in selling the rights to the land because he was in need of some money for certain needs. Therefore, if the transaction price submitted by the taxpayer differs significantly from the data held by the two agencies the taxpayer will be summoned to meet the officer who examined the tax.

As for the principles of tax collection according to Erly Suandy, as follows:

\section{Equality}

The tax imposition among tax subjects should be balanced with their ability, balanced with the income they enjoy under government protection. In the case of equality, it is not allowed for State to discriminate among taxpayers. In same conditions as Taxpayers must be treated the same and in different circumstances Taxpayers must be treated differently.

2. Certainty 
Taxes paid by taxpayers must be clear and not compromise (not arbitrary). In this principle, legal certainty is prioritized regarding tax subjects, tax objects, and provisions regarding payment.

\section{Convenience of payment}

Taxes should be collected at the best time for taxpayers, ie when they are as close as possible to the receipt of income / profits subject to tax.

\section{Economic of collection}

Tax collection should be done as economically (efficiently) as possible, lest the cost of tax collection is greater than the tax revenue itself. Because there is no meaning to tax collection if the cost issued is greater than the tax revenue to be obtained. In the principle of tax collection there is Equality which means that tax imposition among tax subjects should be balanced with their ability, balanced with the income they enjoy under government protection. In this equality right, the state is not allowed to discriminate among taxpayers, under the same circumstances taxpayers must be treated the same and in different circumstances taxpayers must be treated differently. Tax collection both in BPHTB and Income Tax, officials and related agencies examine the tax correctly by taking into account the evidence presented by the taxpayer. If it can be proven correctly by the taxpayer, the officer can accept it. So the taxpayer does not feel burdened by the tax he has to pay to state.

So that collection does not cause obstacles or resistance, then there are conditions that must be met in the implementation of tax collection, as follows:

1. Justice Condition (Tax collection must be fair)

In accordance with legal objectives, achieving justice. The law and implementation of collection must be fair. Fair in legislation includes taxing fairly and evenly, and adjusted to their respective abilities.

2. Juridical Condition (Tax collection must be based on the law)

In Indonesia, taxes are regulated in the 1945 Constitution article 23 paragraph 2 . This provides a legal guarantee to declare justice, both for the country and its citizens.

3. Economic Condition (Collections may not interfere with the economy)

Tax collection should running smoothly in production and trade activities, so as not to cause decrease in the economy of the community.

\section{Financial Condition (Tax collection must be efficient)}

In accordance with budget function, cost of tax collection must be reduced so that it is lower than collection result.

5. Tax Collection System must be Simple

This will facilitate and encourage the community to fulfill their tax obligations. This condition has been fulfilled by the new Law.

One of the conditions for tax collection is justice condition. It is to impose a tax fairly and equally, and be adjusted to the capabilities of each. In collecting BPHTB and Income Tax, it can pay attention to the element of justice in it. Justice here is the collection carried out by both agencies both BKD and Primary Tax Service Office.

In collecting taxes known 3 tax collection systems, as follows:

\section{Official Assessment System}

A tax collection system that allows taxation apparatus to determine the amount of tax owed each year in accordance with applicable tax laws and regulations. In this system, the initiatives and activities of calculating and collecting taxes are entirely in the hands of the taxation apparatus. Thus, the success or failure of the implementation of tax collection depends a lot on tax apparatus (dominant role is in tax apparatus).

\section{Self Assessment System}

A tax collection system that allows taxpayers to determine their own amount of tax owed each year in accordance with applicable tax laws and regulations. In this system, initiatives and activities of calculating and collecting taxes are entirely in the hands of taxpayers. Taxpayers are considered capable of calculating taxes, able to understand current tax laws, and realize the importance of paying taxes. Therefore, taxpayers are given the trust to:

a. Calculate the tax owed himself

b. Calculating the tax payable himself

c. Paying the amount of tax owed himself

d. Self-report the amount of tax owed

e. Take responsibility for tax owed 
Thus, the success or failure of the implementation of tax collection depends a lot on the taxpayer himself dominant role is the taxpayer).

\section{With Holding System}

A tax collection system that authorizes appointed third parties to determine the amount of tax owed by taxpayers in accordance with applicable tax laws. The appointment of third party is carried out in accordance with tax legislation, presidential decrees, and other regulations to cut and collect taxes, deposit and account for through available taxation facilities. The success or failure of the implementation of tax collection depends a lot on the appointed third parties. The characteristics and trait of tax collection system based on the general explanation of Law Number 6 of 1983 concerning General Provisions and Tax Procedures are:

a. tax collection is dedication embodiment of Taxpayer obligation and participation to directly and jointly carry out the tax obligations required for state financing and national development;

b. responsibility for the implementation of tax obligations, as a reflection of obligations in taxation field lies with Taxpayers themselves. The Government, in this case the taxation apparatus in accordance with its function is obliged to conduct guidance, research and supervision of the implementation of taxpayers' tax obligations based on the provisions outlined in the taxation legislation;

c. Taxpayers' community members are given the trust to be able to carry out national mutual cooperation through a system of calculating, estimating, and self-paying tax owed (self assessment), so that through this system the implementation of tax administration is expected to be carried out more neatly, in a controlled, simple and easy to be understood by Taxpayers community members.

Based on the three principles of tax collection, taxpayers are required to calculate, estimate, and pay their own amount of tax that should be owed in accordance with the provisions of tax legislation, so that the determination of the amount of tax owed lies with the taxpayers themselves. Apart from that, taxpayers are also required to report regularly the amount of tax owed and paid as determined in tax legislation. With this system it is hoped that the convoluted and bureaucratic tax administration will be eliminated. Legal certainty can contain several meanings, clarity, does not cause multiple interpretations, does not cause contradictions, and can be implemented. The law must apply firmly in society, containing openness so that anyone can understand the meaning of a legal provision. One law with another must not be contradictory so that it does not become a source of doubt. Legal certainty becomes a legal instrument of a country that contains clarity, does not cause multiple interpretations, does not cause contradictions, and can be implemented, which is able to guarantee the rights and obligations of every citizen in accordance with the existing culture of society.

In determining actual transaction price based on legal certainty theory above, it needs to be clarified in terms of regulations. Both the law and the local regulation are written in the sale and purchase of land and / or building based on the transaction price. Transaction prices need to be explained in more detail. So it does not cause multiple interpretations, does not cause contradictions, and can be carried out, which is able to guarantee the rights and obligations of every citizen in accordance with the existing culture of society. This is because there are differences in the prices submitted by taxpayers with data held by BKD and Primary Tax Service Office. So there are two kinds of prices that are contradictory. One side of taxpayer is the correct price based on the agreement between the seller and the buyer. While the two agencies have their own data about transaction price according to the agency is the price that should occur. Both two prices that arise there is uncertainty, which ones will be used into the Sale and Purchase Agreement which is used for transferring rights process of sale and purchase at Land Office.

\section{Closing}

\section{Conclusions}

Based on results above, concluded that tax collection in BPHTB form conducted at the district / city level needs to be regulated using local regulations. For Karanganyar District itself regarding BPHTB regulated by Karanganyar Regional Regulation Number 14 Year 2010 Concerning Acquisition Charges for Land and Building Rights. In this local regulation regulates the amount of tariffs that need to be paid by taxpayers, the procedure for collection, and sanctions. This regulation refers to Law Number 28 Year 2009. In determining the actual transaction price based on the legal certainty theory above, it needs to be clarified in terms of regulations. Both the law and the local regulation are written in the sale and purchase of land and / or building based on the transaction price. Transaction prices need to be explained in more detail. So it does not cause multiple interpretations, does not cause contradictions, and can be carried out, which is able to guarantee the rights and obligations of every citizen in accordance with the existing culture of society.

\section{Suggestions}

Based on the results, the author can provide suggestions as follows: 


\section{To Government}

The government in this case is Karanganyar government which collects BPHTB in collecting taxes should pay attention to justice principle in collecting the sale and purchase tax of land and / or building rights. So that people who will pay taxes do not feel burdened by taxes they have to pay. The tax will also be used by government to build infrastructure in the regions. In addition, local governments can also make more strong regulations regarding land prices in accordance with research conducted by officials in authority.

\section{To Community}

In paying the sale and purchase tax of land and / or building rights, the community must also be honest about the actual transaction price. So that in paying taxes the next process can be done that is tax validation quickly and easily without requiring a long time.

\section{Bibliography}

Brotodiharjo, R. Santoso.(1987).Pengantar Ilmu Hukum Pajak, Cet. 3. Bandung : PT. Eresco

Ismail, Nurhasan.(2007).Perkembangan Hukum Pertanahan: Pendekatan Ekonomi Politik.Kerjasama Huma dan Magister Hukum UGM, Yogyakarta

Kusumaatmadja, Mochtar.Fungsi dan Perkembangan Hukum dalam Pembangunan Nasional. Bandung: Binacipta

Muhammad, Abdulkadir.(2004). Hukum dan Penelitian Hukum, Bandung: PT. Citra Aditya Bakti

Resmi, Siti.(2014).Perpajakan Teori dan Kasus. Jakarta: Salemba Empat

Siahaan ,Marihot Pahala.(2013).Pajak Daerah \& Retribusi Daerah. Jakarta:PT Rajagrafindo Persada

Sidharta. (2006).Moralitas Profesi Hukum: Suatu Tawaran Kerangka Berpikir. Bandung: Refika Aditama

Soekanto, Soerjono \& Sri Mamudji.(2001).Penelitian Hukum Normatif (Suatu TinjauanSingkat). Jakarta: Rajawali Pers

Soemitro, Rochmat.(1979).Dasar-Dasar Hukum Pajak Dan Pajak Pendapatan. Bandung : PT. Eresco

W.F. Prins dalam Philipus M. Hadjon, et. al..(2008).Pengantar Hukum Administrasi Indonesia. Yogyakarta:Gadjah Mada University Press 